\title{
Inequality in Education and Economic Growth: Empirical Investigation and Foundations - Evidence from MENA Region
}

\author{
Aomar Ibourk $^{1} \&$ Jabrane Amaghouss ${ }^{1}$ \\ ${ }^{1}$ Faculty of Law, Economics and Social Sciences, Cadi Ayyad University, Morocco \\ Correspondence: Jabrane Amaghouss, Massira 1, Bloc A No 633, Marrakech, Morocco. Tel: 21-266-709-1398. \\ E-mail: jabrane_widadi@yahoo.fr
}

Received: October 17, 2012

Accepted: January 2, $2013 \quad$ Online Published: January 10, 2013

doi:10.5539/ijef.v5n2p111

URL: http://dx.doi.org/10.5539/ijef.v5n2p111

\begin{abstract}
This paper investigates empirically the extent of educational inequality and its impact on economic growth. Based on Barro and Lee's (2010) data, we calculate two indicators measuring inequality of education. The sample comprises 15 countries from the MENA region over the period 1970-2010. As a second step, we applied the Kuznets curve of education for each country of the sample. As a third step, we examine the impact of education inequality on the economic growth in MENA region by using OSL and Instrumental Variables panel regressions with country fixed-effects.

The findings show a decline in the Gini index within all the countries, for men and women and also for all age groups. The results also indicate that the education distribution was more unequal in the middle-income countries than in the higher-income countries in 2010. The results suggested that the shape of the Kuznets curve depends basically on the measure used to approximate the inequality.

The results demonstrate also that the Gini index of men negatively and significantly affects the growth of higher-income countries. At the same time, the total Gini index influenced negatively and significantly the economic growth of all the countries, including those of high income. These results are therefore robust for the used econometric techniques.

In terms of economic policy, the results suggest policymakers to focus on educational policies apt to reduce educational inequalities, especially for women, to improve the well being of the population.
\end{abstract}

Keywords: educational inequality, Kuznets curve, economic growth, MENA

\section{Introduction}

Education plays a key role in the economic and social development processes of all countries. In fact, it helps to reduce poverty and to enhance the quality of social life. It is a basic ingredient within the strategies of improving health conditions. It also helps to decrease social, cultural and ethnic disparities among populations of the same country. From an economic perspective, the level of education and its distribution within the population plays a crucial role in the prospects of income distribution and consequently in economic growth. Indeed, an increased level of education of a person leads to increased skills held by the workforce, which makes it possible to improve labor productivity and therefore economic growth (Barro and Lee, 1993, 1997; Barro and Sala-I-Martin, 1995; Aghion and Howitt, 1998). Although the majority, if not all, of the countries in the world have been aware of the fundamental role that education may have in economic and social development processes, many of these countries are far from achieving mass education.

Does education encourage or discourage economic growth? A large body of empirical investigation has tried to response to this query during the last fifty years. As result, the literature so far has not provided a conclusive answer to the problematic. Over the past decade, many studies have accorded a huge importance to the possible role of equity in education in the development of countries and few of them have examined the impact of inequality in education on economic growth.

If education is not equally distributed among the population, a large part of the revenue will be owned by a well-educated minority, which engenders huge inequalities in the distribution of incomes which causes more poverty (Glomm and Ravikumar, 1992; Lopez et al., 1998). However, there is no agreement on the ideal measurement of inequalities in education. In this regard, the Gini index, developed by the statistician Gini, is the 
most widely used measure. It has been used to describe the inequality of household income.

The Gini coefficient for education goes back to the 70s with the previous works of Ter Weele (1975), Rosthal (1978), Maas and Criel (1982) and Sheret (1982, 1988). In the same context, Maas and Criel's (1982) contribution is considered to be the first fully expressed attempt to allow the Gini coefficient to be calculated to measure educational inequalities. As a fact of matter, their work mainly focused on this coefficient on schooling data of 15 countries. Thomas, Wang and Fan (2002) defined the Gini coefficient as the weighted sum of absolute differences of education levels of a population. They applied this coefficient to 140 countries from 1960 to 2000 , and the attained results demonstrated a drop in the level of educational inequalities for most of the countries of the world, but with a significant improvement for some countries such as South Korea, Tunisia and China, in contrast to countries like Mali and Afghanistan where the Gini index of education showed an unequal distribution of about 0.9. Zhand and Li. (2002) examined the international inequalities and the convergence of educational levels from 1960 to 1990. They showed that the difference in schooling level between the developed and the developing countries on the one hand, and between men and women on the other, was still increasing during the same period. However, as many studies have maintained, the schooling level dispersion, as measured by the coefficient of variation and the Gini coefficient, declined during this period irrespective of gender or the countries' stages of development. Qian and Smyth (2008) considered a measure of the educational inequality between the coastal and inland provinces of China. They compared it to the urban-rural educational inequality by using the Gini index of education. The findings strongly suggested that the major cause behind the educational inequality in China resulted from the access to schooling disparity between the rural and urban areas in 2000 . Sahn and Younger (2007) agreed with the notion that Sen $(1979,1987)$ promoted. The latter confirms that income is not a sufficient measurement for welfare. In fact, both health care and education may constitute the intrinsic aspects that determine individual welfare. Thomas et al. (2002), meanwhile, used the results of the tests carried out by TIMSS in 1999 (38 countries) and in 2003 (49 countries). In the same order, Sahn and Younger used an alternative index named "Generalized entropy". The results show that more than half of the total inequality are due to intra-country differences. In a recent study, Morrison and Murtin (2010) calculated the global inequalities of education and incomes from 1870 to 2000 via an estimation of human capital distribution since 1870 . They suggested that education inequality was quit large in the 1870 s. The Gini coefficient reached 0.79. In $1870,75 \%$ of the world population was illiterate. In 2000 , the situation improved significantly so that the Gini index reached almost half of what it measured in 1870 . This rapid decline refers basically back to the increase in the literacy rate which became $88 \%$ in 2000 compared to $15 \%$ in 1870 .

This work differs from others in the sense that, to our knowledge, no work has attempted to develop a measure of inequality in education in the MENA region and no work has examined its impact on economic growth. To address this question, we combine tree approaches. First, we develop a new data set on educational inequality in order to place disparities between countries in a larger regional context. Second, we use the results to test the validity of the Kuznets curve hypothesis in the field of education. Third, we examine trends of educational inequality on economic growth. MENA countries concerned by this study are: Jordan, Turkey, Iran, Syria, Algeria, Tunisia, Egypt, Iraq, Morocco, Bahraîn, United Arab Emirates, Saudi Arabia, Kuwait, Libya and Qatar. To check the robustness of the results, we divided the sample into two groups: high-income countries and middle-income countries. The period analyzed runs from 1970 to 2010.

The paper is organized as follows. The second section of this paper will deal with the literature review about the impact of education inequalities on economic growth. The third section develops the Gini index of education and discusses the results of our calculations in the MENA region. The fourth section will test the Kuznets hypothesis in the field of education. The fifth will shed light on some empirical investigations which focus on the relationship between inequality in education and economic growth in MENA region. The last section is a conclusion.

\section{Educational Inequality and Economic Growth: Literature Review}

Several indicators have been used in the research papers to measure the impact of the different aspects related to education upon economic growth: enrollment rates in different education cycles, completion rates, survival rates to the last grade of primary education, the average years of schooling, and the obtained test scores following the international standards (Altinok, 2007). Otherwise, works that deal with the measurement of the impact of inequality in education on economic growth are less numerous. In fact, it is important to distinguish two types of impact studies: those related to gender inequalities (Barro and Lee, 1993, 1997; Lagerlöf, 1999; Klasen and Lamanna, 2008) and those related to distribution (Thomas et al., 2002).

Schultz (1993) affirmed that the low investment in girls' education is not economically effective. Schultz goes so 
far as to emphasize the absence of studies that have proved that the performance of girls' schooling is lower than that of boys. Biredsall and Londoño (1997) used the standard deviation of schooling (SDS) in order to approximate inequalities in education. The study focuses on an estimation of a classical model of economic growth in cross section. The results show that the initial level of inequalities in education (measured by SDS) has a significant negative impact on economic growth. The Inter-American Development Bank (1999), for its part, used the standard deviation of schooling to measure the educational inequality in some Latin American countries. Lopez et al. (1998) calculated the Gini index of education by using the educational level of the population. The authors have tried to explain why the impact of education on economic growth is therefore uncertain. They have then constructed an allocation model which demonstrates the importance of education distribution in economic growth. They have used panel data from 12 Asian and Latin American countries from 1970 to 1994. The attained results have shown that the distribution of education is a key role in illustrating this tenuous connection between education and economic growth. They also show that the unequal distribution of education has a negative impact on GDP per habitat for most of the sample countries. Therefore, the effect of education on economic growth is very significant when the equality distribution of education is large. It is concluded, then, that economic policy which does not intend to reduce the inequality of education distribution will reduce or adversely affect the impact of human capital on economic growth. Kalsen (1999) has used cross-sectional and panel data to examine the effect of gender inequality in education on economic growth. The results suggest that there is a direct and negative impact on economic growth and development. This considerable impact is realized through the reduction of human capital quality. On the other hand, economic growth is indirectly affected by the impact of gender inequality on investment and population growth. The outcome also indicates that gender inequality impacts negatively on the reduction strategies of fertility and infantile morality rates. Castelló and Doménech (2002) constructed the Gini index for 108 countries from 1960 to 2000, and the results show a decrease of human capital. After that, they considered a standard economic growth model. The observed results suggest a negative effect of human capital inequalities on economic growth rates. These results are quite robust to the changes in explanatory variables, the exclusion of aberrant data, and the use of instrumental variables as controls of endogeneity problems. De Gregorio and Lee (2002) provided empirical evidence for the way that education can affect the distribution of incomes for a country panel from 1960 to 1990. The findings indicated that a high level of education and its more equal distribution permit a better distribution of incomes. Checchi (2004) studied the relationship between the inequality of education and incomes. The results highlighted that when the negative correlation between the average level of education and its dispersion is taken into consideration, the relationship between the inequality of income and the average years of schooling takes a $U$ shape. In another, more recent study, Klasen and Lamanna (2008) tried to update the comprehensive body of previous works by analyzing the impact of gender inequality in education on economic growth. The outcome suggested that gender inequality reduces the progression potentiality of a country. This negative impact is seen in the MENA region and in South Asian countries. According to them, the rate of economic growth decreases to $0.1 \%$ while the gender inequality in education increases to $0.9 \%$.

More recently, Klasen and Lamanna (2009), using cross-country and panel regressions for the period 1960-2000, investigate to what extent gender gaps in education (Female-male ratio of schooling \& Female-male ratio of the growth in the years of schooling reduce economic growth. They find that gender gaps in education reduce economic growth through its effects on investment rates. Castelló (2010b), by using Gini index of education and the distribution of education by quintiles, find a negative effect of income and human capital inequality on economic growth, both in the sample as a whole and in the low and middle income economies, an effect that vanishes or becomes positive in the higher-income countries.

\section{The Measure of Inequality in Education in The MENA Region}

We relied on Thomas and al. (2002) formula to measure education inequality in the MENA region in order to construct the Gini index of education. This index considers the distribution of schooling years amongst the population:

$$
\text { Egini }=\frac{1}{\mu} \sum_{i=2}^{n} \sum_{j=1}^{i=1} P_{i}\left\langle Y_{i}-Y_{j}\right\rangle P_{j}
$$

With the Egini index of education, which depends on schooling level, $\mu$ is the average years of schooling of the population, $\mathrm{P}_{\mathrm{i}}$ and $\mathrm{P}_{\mathrm{j}}$ represent the parts of the population having $i$ and $j$ schooling levels, $\mathrm{Y}_{\mathrm{i}}$ and $\mathrm{Y}_{\mathrm{j}}$ are the accumulation of the school years according to each level of education, and $n$ is the number of school levels. The classification of Barro and Lee (2010) identifies seven levels of schooling.

In this paper, we have assumed that the duration of each level $Y i$ remains constant throughout the entire period 
and is identical for all the countries.

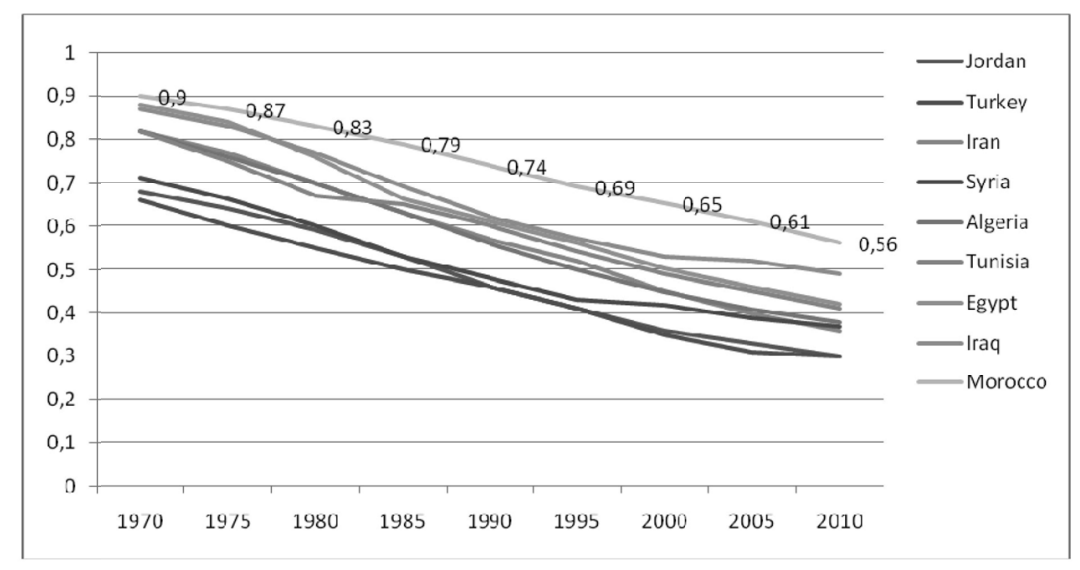

Figure 1. The evolution of the Gini index of education in the MENA region, 1970-2010

Source: Authors' realization based on our calculation and database of Barro and Lee (2010).

Figure 1 shows the evolution of the Gini index in 15 countries of the MENA region (distributed according to income level) in the period between 1970 and 2010. In fact, in 1970, the countries of the MENA region recorded very high indices in educational inequalities. For all the middle-income countries, the inequalities in education were very strong: for example, Morocco (0.90), Egypt (0.88) and Iraq (0.87). After that, in 2010, the situation clearly improved among all the countries of the MENA region. This is broadly in line with the outcomes of Thomas et al. (2002). The lowest values are seen in high-income countries. However, the decline rates of the Gini index of education vary from one country to another. Indeed, in countries like the United Arab Emirates, Bahrain, Egypt, Jordan and Algeria, the Gini index declined by at least $45 \%$ in the period between 1970 and 2010. However, for other countries like Morocco, the inequalities declined slowly within the same period.

The remarkable divergences between the countries of the MENA reflect the divergence of efficiency of efforts devoted by each country to reducing inequalities of access to different levels of education.

As can be deduced from Our calculation, Morocco is the country where the inequalities in education are most pronounced compared with the sample of this study. This outcome is easily understood when we take into consideration the fact that in Morocco we can find the highest illiteracy rates and the lowest average years of schooling of the sample.

Our results confirm those of Thomas et al. (2000), that even if the countries of the MENA region managed to reduce the Gini index of education between 1960 and 2000, they were still far from the performances achieved by countries in other regions of the world, especially those of East Asia and Latin America.

Our data shows also that the Gini index and illiteracy rates are positively correlated for the whole sample.

This outcome has strong implications in terms of education policy. This means that the literacy of individuals should be a priority in order to improve the distribution of education within a country and consequently increase the number of schooling years of its people.

The level of inequality in education among women was still obviously higher in 2010 for some middle-income countries of the MENA (Morocco (0.64) and Iraq (0.56)). The countries that managed to significantly reduce the inequality in education were Bahrain and the United Arab Emirates (high-income countries) with respective values of 0.22 and 0.28 . Meanwhile, the other countries showed intermediate Gini index values that ranged from 0.3 to 0.5 .

We can say that inequalities in education were higher for women than men in all middle-income countries and throughout the entire period of study. This mainly reflects the discrimination that affected women in the schooling process. In addition, it is revealed that the educative policies in the MENA region neglected female schooling. For some countries (especially high-income countries), the distribution of access to school for men was more unequal than for women at certain times: Kuwait (1985, 1990 and 2010); Libya (2005, 2010); Qatar (from 1980 to 2010) and the United Arab Emirates (from 1985 until 2010).

A gap analysis of the Gini index between men and women has shown that Morocco was the only country where 
this gap (deviation) continued to increase. It doubled between 1970 and 2005 respectively from 0.08 to 0.17 before declining by one degree and eventually stabilizing at 0.16 . This gap continued to narrow in some countries like Jordan, Libya, Syria and Turkey in the period between 1970 and 2010. However, for other countries the gap between the two indices continued to rise until the period 1985-1990. After that, it started to fall between the years 1990 and1995. Generally speaking, these inequalities were reduced between 1970 and 2010 for both genders and in all the countries (see Amaghouss and Ibourk, 2012).

The database of Barro and Lee (2010) has provided us with age-group data sets; these allow us to calculate the level of inequality by age groups.

In 2010, a highly increased Gini index for the 15-19 age group was noticed in Morocco (0.38) and a very low value in Qatar and Saudi Arabia (0.12), followed by Jordan (0.13) (see Figure 2 ). The most unequal age group was the 75 years and over group. This simply concerns old people who could not benefit from schooling in the sense that when they were young the majority of the MENA regions were European colonies. Figure 2 shows the evolution of inequality in education for two age group (75 and over, and 15-19 age group). It shows that inequality in education have remained high for older (the upper line is almost horizontal). The same trend is also observed in Algeria. For countries such as Turkey and Syria, inequality decreased significantly for older people. This demonstrates the divergence of political education systems. In both countries, mass schooling was accompanied with a literacy process. Morocco has long neglected adult literacy. Recently, efforts have been made but they remain insufficient given the magnitude of this phenomenon.

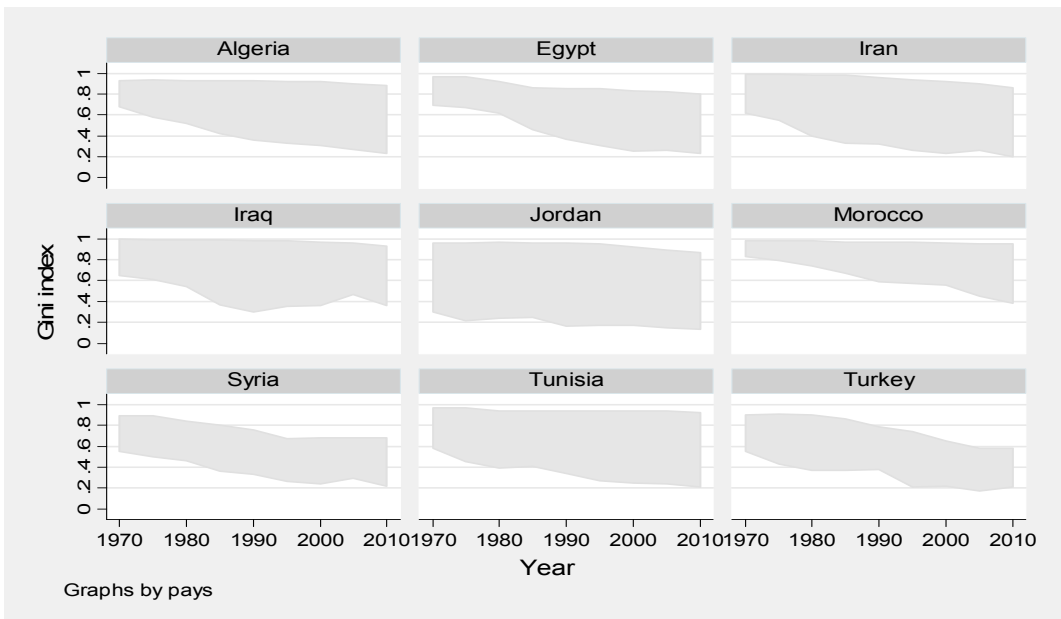

Figure 2. Educational inequality by age group (the upper line: 75 and plus; the lower line: 15-19 age group), Middle-income countries, selected countries, 1970-2010

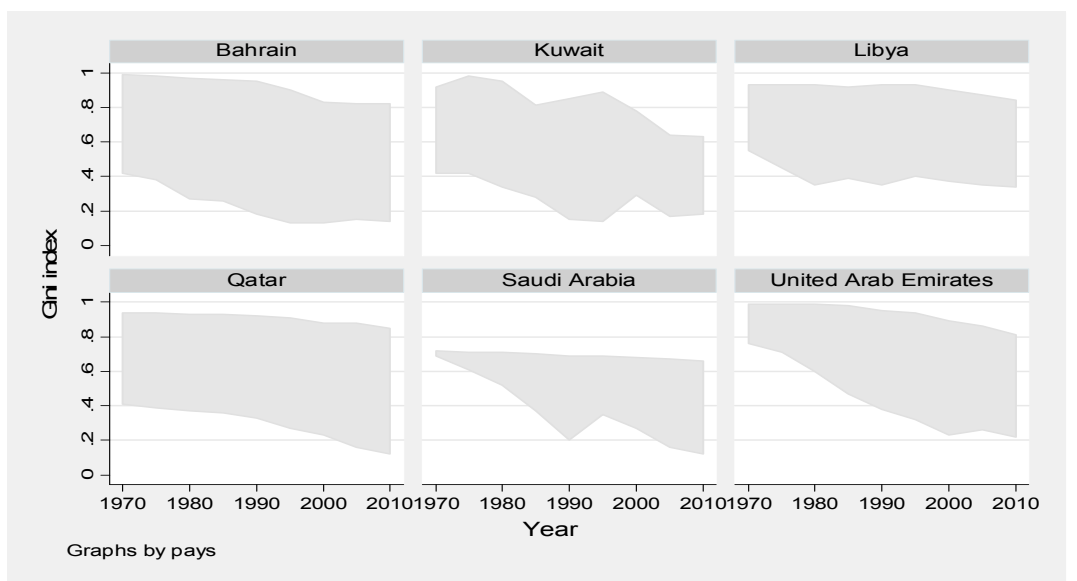

Figure 3. Educational inequality by age group (the upper line: 75and plus; the lower line: 15-19 age group), High-income countries, selected countries, 1970-2010 


\section{Macro-economic Foundations of Inequality in Education: Kuznets Curve of Education Approach}

\subsection{Foundations of the Kuznets Curve}

The implementation of the Kuznets hypothesis in the area of education requires a process of mass schooling in order to achieve a reduction of inequality in access to schooling. This section investigates how the MENA region countries are positioned in relation to this hypothesis.

It is therefore of high interest to test the shape of the Kuznets curve of this region and subsequently establish a sufficiently informative estimation of the turning point. We extend these tests by taking into consideration two groups of countries: high-income and middle-income countries. This choice is more appropriate as the MENA region countries do not constitute a completely homogenous group.

Afterwards, we will carry out an empirical test on the relationship form that links the level of education inequalities and the average years of schooling. The specification of the Kuznets curve in the education field for a panel of countries is given by:

$$
e i_{i t}=a+b \mu_{i t}+c \mu_{i t}^{2}+\varepsilon_{i t}
$$

Where $i$ represents the countries and $t$ indicates the date. In order to study the shape of the Kuznets curve in the field of education in the long term, we have constructed five-year data which last from 1970 to 2010. ei refers to the measure of inequality in the education field. The derivation of the turning point from the equation (2) is detailed in Amaghouss and Ibourk (2012). We have chosen two measures: the standard deviation of school enrollments (De Gregorio and Lee, 2002; Lim and Tang, 2008; Morrison and Murtin, 2010) and the Gini index (GI) as calculated above.

The standard deviation of the distribution of schooling (SDS) is given by the following formula.

$$
S D S=\sqrt{\sum_{i=1}^{n} p_{i}\left(y_{i}-\left(\sum_{i=1}^{n} p_{i} y_{i}\right)\right)^{2}}
$$

\subsection{Findings}

4.2.1 The Standard Deviation of Schooling as a Measure of Inequalities

Figure 4 and 5 present the shape of the Kuznets curve in the field of education for the countries of the MENA region from 1970 to 2010. The figures analysis indicates to us the validity of the Kuznets curve of education for each group of countries. The high-income countries have already entered the second phase of reducing inequality while middle-income countries are still in the first phase of rising inequality except for Syria, Turkey, Jordan and Iran. The figure also provides us with an initial estimation of the turning point which lies between 5 and 7 years.

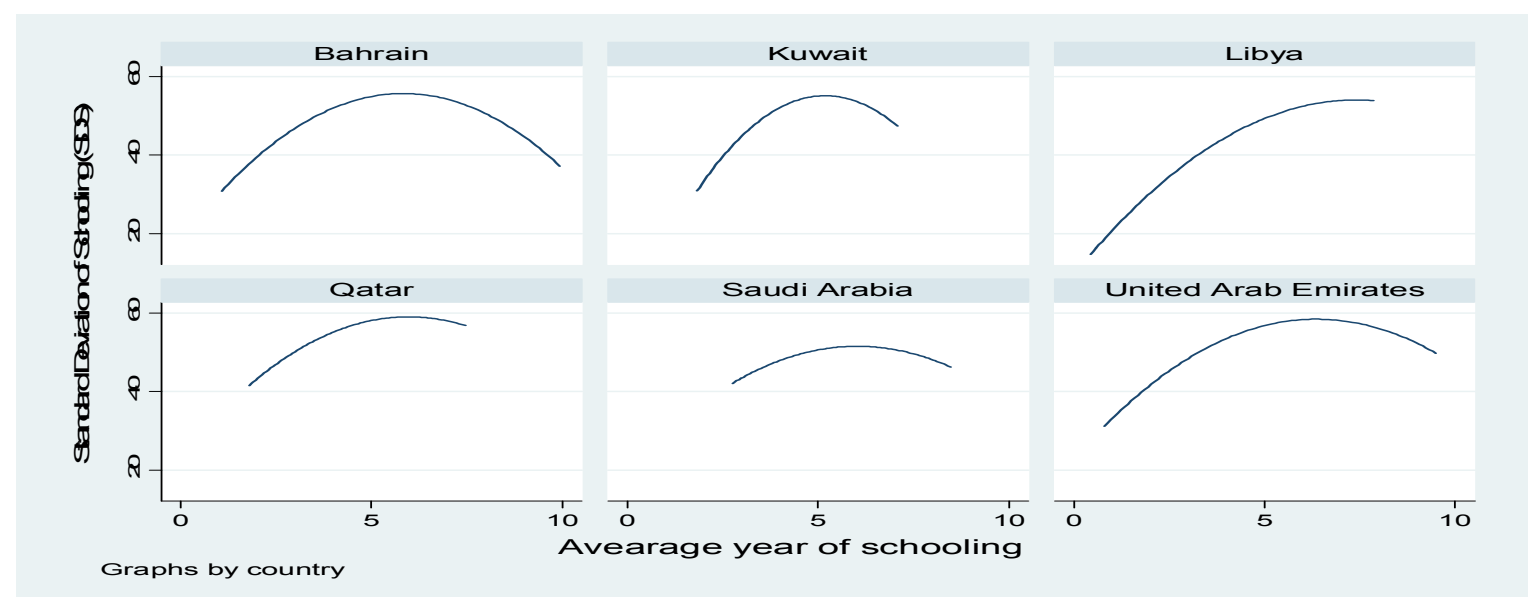

Figure 4. The Kuznets curve of education in 15 countries of the MENA region, 1970-2010

Source: Authors' realization based our calculations and database of Barro and Lee (2010) 


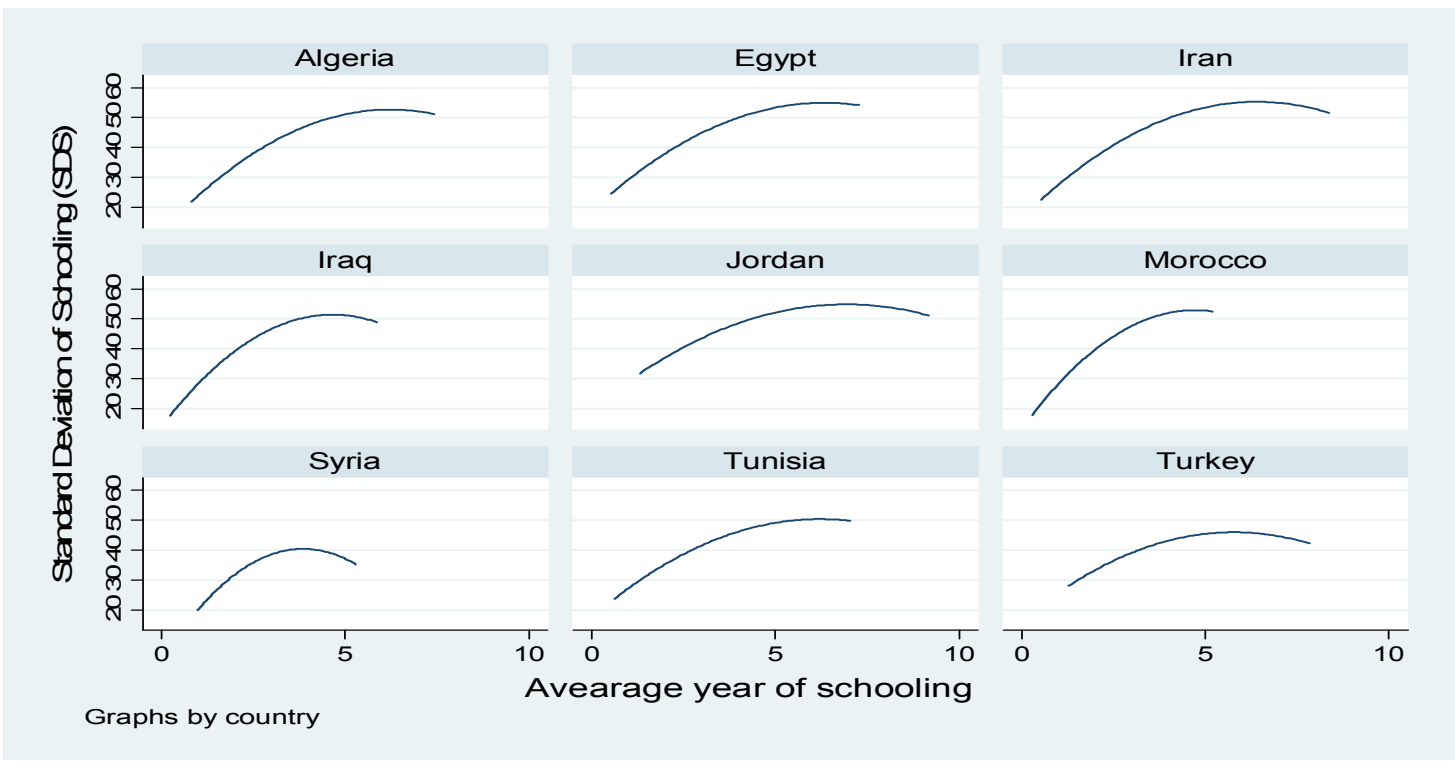

Figure 5. Kuznets curve of education, MENA middle-income countries, selected countries, 1970-2010 Source: Authors' realization based our calculations and database of Barro and Lee (2010)

\subsubsection{The Gini Index as a Measurement of Inequality}

When we use the Gini index as a measurement of inequality, the relationship between the Gini index and the average years of schooling is linear with a negative slope (Figures 6 and 7). The invalidity of the Kuznets curve in the education domain when the inequalities are measured by the Gini index is confirmed in each group of countries.

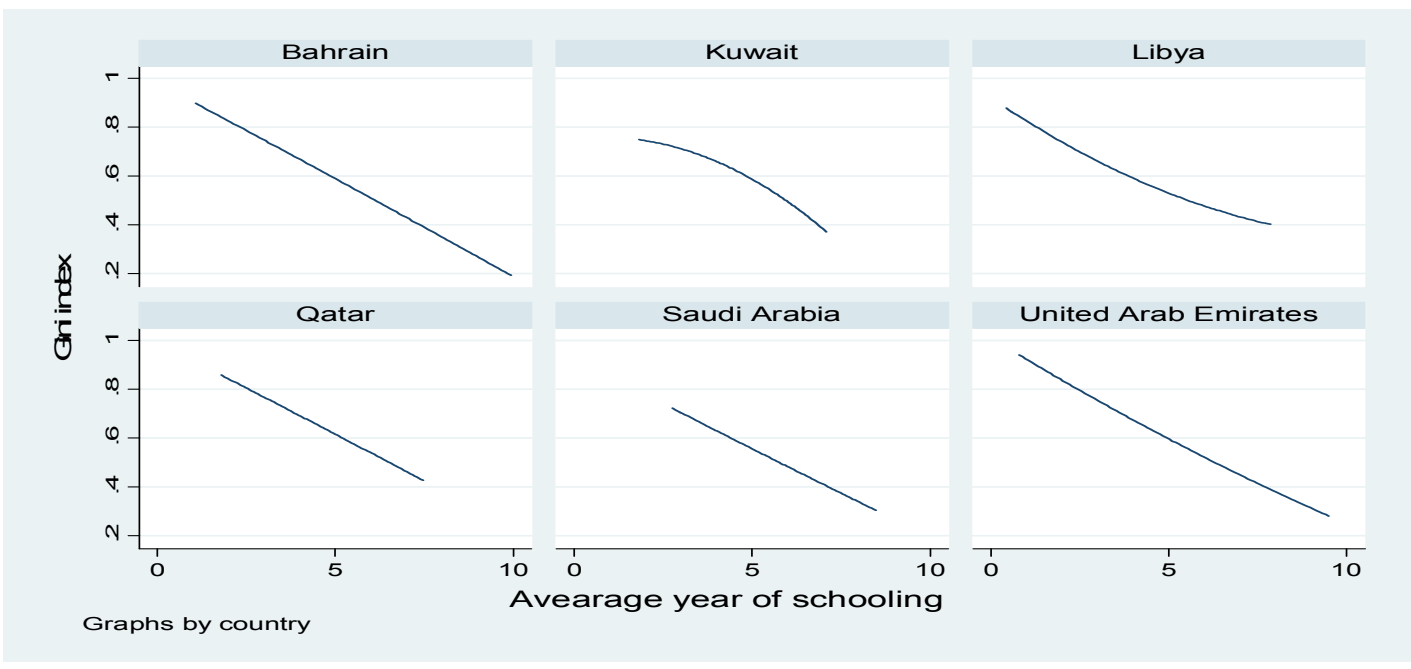

Figure 6. Gini index of education and average year of schooling, MENA high-income countries, 1970-2010 


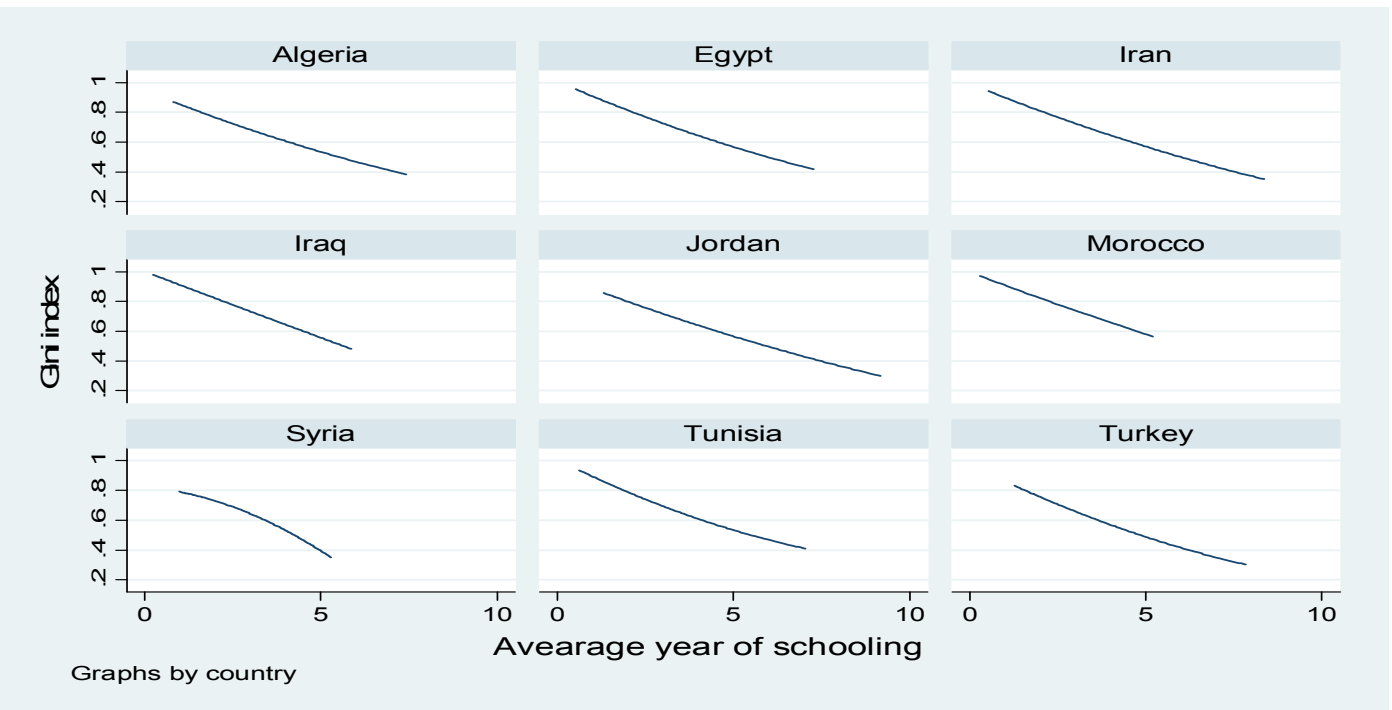

Figure 7. Gini index of education and average year of schooling, MENA middle-income countries, 1970-2010

Using panel regression, Amraghouss and Ibourk (2012) has empirically estimated the shape of the Kuznets curve in MENA region. The finding confirms those of graphical analysis. The results have also estimated the turning point. Its equal to 6.11 years for all the countries (the whole sample), which is equivalent to that argued in the empirical works. This value corresponds to 5.94 years in high-income countries, which is slightly below that observed in middle-income countries (6.28). Indeed, high-income countries are provided with substantial financial sources which permit them to invest more in education. They have managed to start a significant reduction of education dispersion for low levels of schooling year. To better analyze the extent of inequalities in education in the MENA region, we study its impact on economic growth. The following section examines this question.

\section{Inequality in Education and Economic Growth}

\subsection{The Model and Data}

The purpose of this section is to evaluate the impact of education inequality on the economic growth of the MENA region countries.

We use the Gini index of education which we have calculated as a measure of human capital inequality.

To do this, we estimate the following panel regression model with fixed-effects :

$$
L n y_{i t}=\beta_{0}+\beta_{1} \ln s_{k i t}+\beta_{2} \ln \text { pop }_{i t}+\beta_{3} S_{i t}+\beta_{4} G_{i t}^{S}+\eta_{i}+\mu_{t}+\varepsilon_{i t}
$$

Lny $y_{i t}$ : the logarithm of GDP per capita

lns $k_{i t}$ : the logarithm of the investment rate of physical capital

lnpop: the logarithm of the population

$S_{i t}$ : the average years of schooling

$G_{i t}^{S}$ : Gini index of education (for men $\mathrm{S}=\mathrm{m}$, for women $\mathrm{S}=\mathrm{w}$ for all $\mathrm{S}=\mathrm{a}$ )

$\mathrm{n}_{\mathrm{i}}$ : individual's fixed effect

$\mu_{\mathrm{t}}$ : temporal fixed effect

$\varepsilon_{\mathrm{it}}$ : idiosyncratic measurement error

The $\mathrm{y}_{i t}, \mathrm{sk}_{\mathrm{it}}$ and popit data sets were taken from Penn World Table 6.3. The average years of schooling data were obtained from Barro and Lee (2010). The data about the inequalities of education are from our calculations. All the data are calculated in five-year averages from 1970 to 2010. The study has been applied to 15 countries, nine of which are middle-income countries and six are high-income countries.

To better understand the impact of inequality of education upon economic growth, consideration is also given to 
calculating the impact of inequality in education in terms of gender.

The tests of Fisher confirm the existence of fixed effects for all the regressions that we have carried out (the values of the F- test are not carried forward).

\subsection{The Empirical Results}

The regressions (1), (2) and (3) concern the estimation of the model (1) for the whole sample under study by using three measures of inequality in education: the Gini index of men, women, and the total Gini index. The findings indicate that the effect of the physical capital stock is negative and significant irrespective of the chosen measure of inequality in education. This is due to the fact that the stock of physical capital over all the MENA region countries is lower than the long-run equilibrium.

The population effect has a negative sign which is not significant when we take into consideration the total Gini index. This is explained by the fact that in the MENA region, the population growth doesn't encourage economic prosperity in the sense that the additional population cannot find productive employment and therefore joins the millions of the already unemployed population. Indeed, the MENA region has one of the highest unemployment rates in the world (Salehi-Isfahani, 2010).

The education attainment level of the population and the distribution of education affect negatively and significantly the economic growth in regressions (1) and (3). These results reinforce the findings of Pritchett (2001) and Makdissi and al. (2006), to whom education in the MENA region does not contribute to the economic growth.

We have also tested equation (4) in high-income and middle-income countries to identify the disparities between the two sub-groups. For high-income countries, the results suggest that it is only the Gini index of men that has a negative and significant impact on economic growth. This result can be explained by the fact that the Gini index of women is much lower than that of men in some of the high-income countries. For its part, the educational level of the population has not changed sign and remained significant, while the impact of the stock of physical capital is no longer significant.

For the middle-income countries, the negative impact of educational inequality is significant when we take into consideration the total Gini index. Indeed, the distribution of education is highly unequal among women in middle-income countries. For instance, the level of inequality in education for women in Morocco in 2010 was 0.64 while it was only 0.32 for men. In addition, in these countries, the level of accumulation of physical capital does not help to generate economic growth. But when it comes to the population level, this impact is therefore negative and significant (Table 1). 
Table 1. The results of fixed-effects model regression by OLS methods

\begin{tabular}{|c|c|c|c|c|c|c|c|c|c|}
\hline & \multicolumn{3}{|c|}{ The whole sample } & \multicolumn{3}{|c|}{ High-income countries } & \multicolumn{3}{|c|}{ Middle-income countries } \\
\hline & $(1)$ & $(2)$ & (3) & (4) & $(5)$ & $(6)$ & $(7)$ & $(8)$ & $(9)$ \\
\hline \multirow[t]{2}{*}{$\operatorname{Ln}(\mathbf{I} / \mathbf{y})$} & $-0.177^{* *}$ & $-0.180^{* *}$ & $-0.186^{* *}$ & -0.109 & -0.075 & -0.125 & $0.142^{*}$ & -0.119 & $-0.128^{*}$ \\
\hline & $(-2.49)$ & $(-2.35)$ & $(-2.51)$ & $(-0.90)$ & $(-0.59)$ & $(-0.99)$ & $(-1.84)$ & $(-1.55)$ & $(-1.71)$ \\
\hline \multirow[t]{2}{*}{$\operatorname{Ln}($ pop) } & -0.171 & -0.086 & $-0.223^{*}$ & 0.208 & $0.367^{* *}$ & 0.248 & -0.473 & $-0.814^{* *}$ & $-0.873^{* * *}$ \\
\hline & $(-1.377)$ & $(-0.59)$ & $(-1.67)$ & $(1.22)$ & $(2.07)$ & $(1.39)$ & $(-1.96)$ & $(-2.58)$ & $(-3.01)$ \\
\hline \multirow[t]{2}{*}{$\mathbf{S}$} & $-0.138^{* *}$ & 0.108 & $-0.15^{* *}$ & $-0.253^{* * *}$ & 0.064 & $-0.26^{* *}$ & 0.053 & 0.065 & -0.065 \\
\hline & $(-2.47)$ & (1.49) & $(-1.88)$ & $(-3.48)$ & $(0.48)$ & $(-2.26)$ & $(-0.63)$ & $(-0.97)$ & $(-0.67)$ \\
\hline \multirow[t]{2}{*}{ Gini $^{\mathrm{m}}$} & $-3.005^{* * *}$ & & & $-2.306^{* *}$ & & & -1.643 & & \\
\hline & $(-4.17)$ & - & - & $(-2.30)$ & - & - & $(-1.51)$ & - & - \\
\hline \multirow[t]{2}{*}{ Gini $^{w}$} & & 0.725 & & & 2.523 & & & $-2.055^{*}$ & - \\
\hline & - & $(0.78)$ & - & - & (1.6) & - & - & $(-1.91)$ & \\
\hline \multirow[t]{2}{*}{ Gini $^{a}$} & & & $-3.036^{* * *}$ & & & -1.917 & & & $-4.004^{* *}$ \\
\hline & - & - & $(-2.84)$ & - & - & $(-1.23)$ & - & - & $(-2.61)$ \\
\hline \multirow[t]{2}{*}{ Const } & $13.426^{* * *}$ & $9.51^{* * *}$ & $14.175^{* * *}$ & $11.73^{* * *}$ & $6.14^{* * *}$ & $11.384^{* * *}$ & $14.093^{* * *}$ & $17.87^{* * *}$ & $20.36^{* * *}$ \\
\hline & $(11.41)$ & $(5.39)$ & $(6.34)$ & $(7.52)$ & $(2.75)$ & $(8.62)$ & $(5.58)$ & $(4.92)$ & $(-5.47)$ \\
\hline $\begin{array}{l}\text { N. } \\
\text { observations }\end{array}$ & 135 & 135 & 135 & 54 & 54 & 54 & 81 & 81 & 81 \\
\hline \multirow{2}{*}{$F$ test } & Prob $>F=$ & Prob $>F=$ & Prob $>F=$ & Prob $>F=$ & Prob $>F=$ & Prob $>F=$ & Prob $>F=$ & Prob $>F=$ & Prob $>F=$ \\
\hline & 0.0000 & 0.0000 & 0.0000 & 0.0000 & 0.0000 & 0.0000 & 0.0000 & 0.0000 & 0.0000 \\
\hline \multicolumn{10}{|l|}{ R-sq } \\
\hline Within & 0.2 & 0.09 & 0.14 & 0.26 & 0.21 & 0.2 & 0.4 & 0.41 & 0.43 \\
\hline Between & 0.14 & 0.47 & 0.18 & 0.3 & 0.19 & 0.18 & 0.02 & 0.008 & 0.024 \\
\hline Overall & 0.14 & 0.4 & 0.36 & 0.06 & 0.05 & 0.04 & 0.001 & 0.002 & 0.001 \\
\hline
\end{tabular}

$* * * \mathrm{p}<0.01, * * \mathrm{p}<0.05, * \mathrm{p}<0.1$.

Source: author's estimation

By construction, the estimation of equation (4) has provided biased estimators in the measure where the investment rates in physical capital (explanatory variables) are dependent on the level of GDP per habitat (variable to be explained). We have furthermore used various panel data techniques, including instrumental variable ones, in order to control the problem of collinearity. We have also used the lagged value of investment rates in physical capital and the logarithm of the population as an instrument for investment rates in physical capital (Földvári and Van Leeuwen, 2011); and to ensure the correct choice of instruments, we have proceeded to the Sargent test. Anderson Canonical tests aim to judge quality of the instruments used in the models, both reported in the last columns of Table 2 give two important information about the regression. They determine the conditions for identification of the modèls and the validity of the exogenous variables not included in the second stage regression ("Excluded instruments"). The results of the estimations are reproduced in Table 2.

For the entire sample of countries, the achieved outcome of the double least squares method using panel data confirms the results obtained by the OLS method for the variables measuring the educational inequalities. However, the negative impact of education level is insignificant only in the presence of the Gini index of men. The findings confirm and amplify the scale of the negative coefficient associated with the stock of physical capital.

For the high-income countries, the statistical significance and the sign which have associated wih the coefficients measuring the educational inequalities, the education level of the population and the investment rates in the stock of physical capital are altogether not altered. Meanwhile, the positive coefficient associated with the population is the only one which has lost its statistical significance. 
Table 2. The results of fixed-effects regressions by the method of panel data instrumental variables

\begin{tabular}{|c|c|c|c|c|c|c|c|c|c|}
\hline & \multicolumn{3}{|c|}{ The whole sample } & \multicolumn{3}{|c|}{ High-income countries } & \multicolumn{3}{|c|}{ Middle-income countries } \\
\hline & (1) & (2) & (3) & (4) & (5) & (6) & (7) & (8) & (9) \\
\hline $\operatorname{Ln} \mathrm{I} / \mathrm{y}$ & $\begin{array}{l}-0.587^{* *} \\
(-2.30)\end{array}$ & $\begin{array}{c}-0.546^{* *} \\
(-2.08)\end{array}$ & $\begin{array}{l}-0.578^{* *} \\
(-2.22)\end{array}$ & $\begin{array}{l}-0.468 \\
(-1.57)\end{array}$ & $\begin{array}{l}-0.376 \\
(-1.22)\end{array}$ & $\begin{array}{l}-0.479 \\
(-1.50)\end{array}$ & $\begin{array}{l}-0.65 \\
(-1.42)\end{array}$ & $\begin{array}{l}-0.556 \\
(-1.23)\end{array}$ & $\begin{array}{l}-0.558 \\
(-1.38)\end{array}$ \\
\hline Ln (pop) & $\begin{array}{l}-0.384^{*} \\
(-1.95)\end{array}$ & $\begin{array}{l}-0.285 \\
(-1.29)\end{array}$ & $\begin{array}{l}-0.455^{* *} \\
(-2.17)\end{array}$ & $\begin{array}{l}-0.122 \\
(-0.46)\end{array}$ & $\begin{array}{l}0.069 \\
-0.27\end{array}$ & $\begin{array}{l}-0.065 \\
(-0.24)\end{array}$ & $\begin{array}{l}-0.344 \\
(-1.03)\end{array}$ & $\begin{array}{l}-0.537 \\
(-1.02)\end{array}$ & $\begin{array}{l}-0.69^{*} \\
(-1.83)\end{array}$ \\
\hline $\mathbf{S}$ & $\begin{array}{l}-0.123^{*} \\
(-1.64)\end{array}$ & $\begin{array}{c}0.068 \\
(-0.82)\end{array}$ & $\begin{array}{l}-0.145 \\
(-0.25)\end{array}$ & $\begin{array}{l}-0.195^{* *} \\
(-2.22)\end{array}$ & $\begin{array}{c}0.025 \\
(-0.17)\end{array}$ & $\begin{array}{l}-0.229^{*} \\
(-1.68)\end{array}$ & $\begin{array}{l}-0.063 \\
(-0.34)\end{array}$ & $\begin{array}{l}0.048 \\
(-0.6)\end{array}$ & $\begin{array}{l}-0.075 \\
(-0.56)\end{array}$ \\
\hline Gini $^{\mathrm{m}}$ & $\begin{array}{c}-3.085^{* * *} \\
(-3.46)\end{array}$ & . & - & $\begin{array}{l}-2.522^{* *} \\
(-2.18)\end{array}$ & (2) & 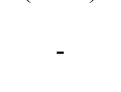 & $\begin{array}{l}-2.541 \\
(-1.21)\end{array}$ & 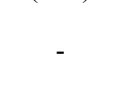 & 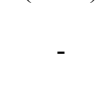 \\
\hline Giniw $^{w}$ & - & $\begin{array}{l}0.0713 \\
(-0.07)\end{array}$ & - & - & $\begin{array}{c}1.296 \\
(-0.74)\end{array}$ & - & - & $\begin{array}{l}-1.236 \\
(-0.86)\end{array}$ & - \\
\hline Gini $^{\mathbf{a}}$ & - & (a) & $\begin{array}{c}-3.483^{* * *} \\
(-4.05)\end{array}$ & - & 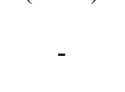 & $\begin{array}{l}-2.461 \\
(-1.33)\end{array}$ & - & - & $\begin{array}{r}-3.316^{*} \\
(-1.7)\end{array}$ \\
\hline Const & $\begin{array}{c}16.476^{* * *} \\
(-9.86)\end{array}$ & $\begin{array}{c}12.959^{* * *} \\
(-5.77) \\
\end{array}$ & $\begin{array}{c}17.483^{* * *} \\
-6.589\end{array}$ & $\begin{array}{c}14.97^{* * *} \\
(-6.8) \\
\end{array}$ & $\begin{array}{c}10.092^{* * *} \\
(-3.57) \\
\end{array}$ & $\begin{array}{c}14.81^{* * *} \\
(-5.11) \\
\end{array}$ & $\begin{array}{l}15.29^{* * *} \\
(-4.62) \\
\end{array}$ & $\begin{array}{l}15.98^{* * *} \\
(-3.09) \\
\end{array}$ & $\begin{array}{c}19.16^{* * *} \\
(-4.31) \\
\end{array}$ \\
\hline $\mathbf{N}$ & 120 & 120 & 120 & 48 & 48 & 48 & 72 & 72 & 72 \\
\hline F test & $\begin{array}{c}\text { Prob }>F= \\
0.0000\end{array}$ & $\begin{array}{c}\text { Prob }>F= \\
0.0000\end{array}$ & $\begin{array}{c}\text { Prob }>F= \\
0.0000\end{array}$ & $\begin{array}{c}\text { Prob }>F= \\
0.0000\end{array}$ & $\begin{array}{c}\text { Prob }>F= \\
0.0000\end{array}$ & $\begin{array}{c}\text { Prob }>F= \\
0.0000\end{array}$ & $\begin{array}{c}\text { Prob }>F= \\
0.0000\end{array}$ & $\begin{array}{c}\text { Prob }>F= \\
0.0000\end{array}$ & $\begin{array}{r}\text { Prob }>F= \\
0.0000\end{array}$ \\
\hline R-sq & & & & & & & & & \\
\hline Within & 0.15 & 0.14 & 0.12 & 0.003 & 0.02 & 0.01 & 0.2 & 0.25 & 0.27 \\
\hline Between & 0.27 & 0.38 & 0.4 & 0.25 & 0.18 & 0.11 & 0.32 & 0.12 & 0.13 \\
\hline Overall & 0.21 & 0.26 & 0.38 & 0.02 & 0.02 & 0.008 & 0.07 & 0.02 & 0.03 \\
\hline $\begin{array}{l}\text { Anderson canon. } \\
\text { corr. test }\end{array}$ & $\begin{array}{c}6.907 \\
(0.3296)\end{array}$ & $\begin{array}{c}7.842 \\
(0.3518)\end{array}$ & $\begin{array}{c}5.692 \\
(0.31872)\end{array}$ & $\begin{array}{c}8.973 \\
(0.4379)\end{array}$ & $\begin{array}{c}7.893 \\
(0.34619)\end{array}$ & $\begin{array}{c}9.836 \\
(0.4582)\end{array}$ & $\begin{array}{c}4.581 \\
(0.274)\end{array}$ & $\begin{array}{c}4.663 \\
(0.2826)\end{array}$ & $\begin{array}{c}5.852 \\
(0.3196)\end{array}$ \\
\hline Sargan statistic & $\begin{array}{c}23.248 \\
(0.0003)\end{array}$ & $\begin{array}{l}24.654 \\
(0.002)\end{array}$ & $\begin{array}{c}22.251 \\
(0.0025)\end{array}$ & $\begin{array}{c}18.691 \\
(0.0087)\end{array}$ & $\begin{array}{c}17.348 \\
(0.0096)\end{array}$ & $\begin{array}{c}14.894 \\
(0.0108)\end{array}$ & $\begin{array}{l}21.372 \\
(0.009)\end{array}$ & $\begin{array}{c}20.652 \\
(0.0104)\end{array}$ & $\begin{array}{c}19.258 \\
(0.0101)\end{array}$ \\
\hline
\end{tabular}

For the middle-income countries, the negative impact of the physical capital stock coefficient becomes insignificant. At the same time, the coefficient associated with the population also becomes insignificant in the presence of the Gini index of men and women. After the correction of biases related to the presence of collinearity among some variables, the coefficient associated with the Gini index of women loses its statistical significance.

The results appear to suggest that the negative impacts of the Gini index of men on high-income countries and the negative impacts of the total Gini index on all the countries, including the middle-income ones, are robust in changing the estimation method, thereby confirming the heterogeneous performances of the countries of the MENA region as to the impact of educational inequality on economic growth. Thus, the weakly egalitarian distribution of education characterizing most MENA economies has certainly been an obstacle to the development process in the region.

Several causes explain the negative impact of inequality in education on economic growth. Lagerlöf (1999) confirm that inequality in education affect growth through fertility. The economic growth is indirectly affected through the impact of inequality in education on investment and population growth (King and Mason, 2001). The educational inequalities simultaneously affect growth and income inequality (Dallar and Datti, 1999; Rehme, 2007). More recently, Castelló (2010a) confirm that this negative impact is reinforced in the countries where individuals find it difficult to access credit. Unfortunately, the lack of data in MENA region does not allow us to explore the extent of the transmission channel.

\section{Conclusion and Implications}

The aim of this paper is to measure the extent of inequality in education in the MENA region and its impact on economic growth using the Gini index of education according to the criteria of gender, age and income levels. The results achieved have indicated that educational inequalities explicitly decreased for all the countries, for both men and women and for all age groups. The findings also show that the distribution of education was more 
unequal in middle-income countries than in high-income countries in 2010 while they had almost the same level in 1970. This result is confirmed by the shape of the Kuznets curve. The high-income countries have already entered the second phase of reducing inequality while middle-income countries are still in the first phase of rising inequality.

Secondly, we have estimated the impact of educational inequality on economic growth in the MENA region. It is shown that the Gini index of men affects negatively and significantly the progression of high-income countries. Moreover, the total Gini index has the same impact on the economic growth of the whole MENA region, including the high-income countries.

These results have strong implications in terms of economic policy. For high-income countries, future efforts should be emphasized on the reduction of inequalities in men's education, whereas in middle-income countries, the educational policies should offer programs aimed at reducing the total inequality, with a particular focus on decreasing that of women.

To conclude, it is important to mention some limitations of this research. Firstly, the results show associations but cannot prove causality. Additional analyzes using micro-data will be able to demonstrate the importance of links explored here. Secondly, MENA region is mainly divided in three group: High-income countries, Middle-income countries and low-income countries (low-income countries are excluded due to lack of data). This analysis considered the first two groups to explore the patterns of educational inequalities. It is possible that this simplification might mask the existence of more localized educational growth trajectories. A general comprehension of geographic patterns can be required. It might be interesting to realize further studies regarding spatial inequalities and regional development especially for a country like Morocco. This point will be discussed in a future work.

\section{References}

Aghion, P., \& Howitt, P. (1998). Endogenous Growth Theory. Cambridge, MA. MIT.

Altinok, N. (2007). Essais sur la qualité de l'éducation et la croissance économique. Thèse de Doctorat, Université de Bougogne

Amaghouss, J., \& Ibourk, A. (2012). Measuring education inequalities : concentration and dispersion-based approach; Lessons from Kuznets curve in MENA region. Word Journal of Education, 2(6), 51-65. http://dx.doi.org/10.5430/wje.v2n6p51

Appiah-Kubi, K. (2008). Education Inequality in Ghana: Gini Coefficient of Education. In B. Kouassi (Eds.), Pauvreté des Ménages et Accès à l'Education en Afrique de l'Ouest: Burkina Faso, Côte d'Ivoire, Ghana et Togo. Paris: Editions Karthala

Barro, R. J. (1997). Determinants of Economic Growth: A Cross-Country Empirical Study. Cambridge, MA: MIT Press.

Barro, R. J., \& Lee, J. W. (1993). International Comparisons of Educational Attainment. Journal of Monetary Economics, 32, 363-94. http://dx.doi.org/10.1016/0304-3932(93)90023-9

Barro, R. J., \& Lee, J. W. (1996). International Measures of Schooling Years and Schooling Quality. American Economic Review, 86, 218-23.

Barro, R. J., \& Lee, J. W. (1997). Schooling Quality in a Cross Section of Countries, NBER Working Papers 6198, National Bureau of Economic Research, Inc.

Barro, R. J., \& Lee, J. W. (2010). A New Data Set of Educational Attainment in the World, 1950-2010. NBER Working Paper series 15902. National Bureau of Economic Research, Inc.

Barro, R. J., \& Sala-i-Martin, X. (1995). Technological Diffusion, Convergence and Growth. Economics Working Papers 116, Department of Economics and Business. Universitat Pompeu Fabra, Barcelona.

Birdsall, N., \& Londono, J. L. (1997). Asset Inequality Matters: An Assessment of the World Bank's Approach to Poverty Reduction, American Economic Review, 87, 32-37.

Castelló, A. (2010a). Channels Through Which Human Capital Inequality Influences Economic Growth. Journal of Human Capital, 4(4), 394-450. http://dx.doi.org/10.1086/659338

Castelló, A. (2010b). Inequality and Growth in Advanced Economies: An Empirical Investigation. Journal of Economic Inequality, 8(3), 293-321. http://dx.doi.org/10.1007/s10888-010-9133-4

Castelló, A., \& Doménech, R. (2002). Human Capital Inequality and Economic Growth: Some New Evidence. 
Economic Journal, 112(478), 187-200. http://dx.doi.org/10.1111/1468-0297.00024

Castelló, A., \& Doménech, R. (2008). Human Capital Inequality, Life Expectancy and Economic Growth. Economic Journal, 118(528), 653-677. http://dx.doi.org/10.1111/j.1468-0297.2008.02136.x

Checchi, D. (2004). Does Educational Achievement Help to Explain Income Inequality? In A. Cornia (Eds.), Inequality, Growth and Poverty in an Era of Liberalization and Globalization, Chapter 4. Oxford University Press. http://dx.doi.org/10.1093/0199271410.003.0004

De Gregorio, J., \& Lee, J. W. (2002). Education and Income Distribution: New Evidence from Cross-Country Data. Review of Income and Wealth, 48(3), 395-416. http://dx.doi.org/10.1111/1475-4991.00060

Dollar, D., \& Gatti, R. (1999). Gender Inequality, Income, and Growth: Are Good Times Good for Women?. Policy Research Report On Gender and Development Working Paper Series, No. 1. Development Research Group/PREMN, The World Bank.

Földvári, P., \& Van Leeuwen, B. (2011). Should Less Inequality in Education Lead to a More Equal Income Distribution? Education Economics, 19(5), 537-554.

Glomm, G., \& Ravikumar, B. (1992). Public versus Private Investment in Human Capital Endogenous Growth and Income Inequality. Journal of Political Economy, University of Chicago Press, 100(4), 813-34.

Hojo, M. (2009). Inequality in Japanese Education Estimation Using the Gini Education Coefficient. The Japanese Economy, 36(3), 3-27.

Inter-American Development Bank. (1999). Facing up to Inequality in Latin America: Economic and Social Progress in Latin America, 1998-99 Report. Johns Hopkins University Press.

King, E. M., \& Mason, A. D. (2001). Engendering Development through Gender Equality in Rights, Resources and Voices (Summary). A World Bank Policy Research Report. Washington DC: The World Bank Group.

Klasen, S. (1999). Does Gender Inequality Reduce Growth and Development? World Bank Policy Research Department, Working Paper 7, World Bank: Washington DC.

Klasen, S., \& Lamanna, F. (2008). The Impact of Gender Inequality in Education and Employment on Economic Growth in Developing Countries: Updates and Extensions, EUDN Working Paper 2008-10 (Namur, Belgium: European Development Research Network).

Kuznets, S. (1955). Economic Growth and Income Inequality. American Economic Review, 65(4), 1-28.

Lagerlöf, N. (1999). Gender Inequality, Fertility, and Growth. Mimeo. Department of Economics, University of Sydney.

Lim, A. S. K., \& Tang, K. K. (2008). Human Capital Inequality and the Kuznets Curve. The Developing Economies, 46(1), 26-51. http://dx.doi.org/10.1111/j.1746-1049.2007.00054.x

Londoño, J. L. (1990). Kuznetsian Tale With Attention to Human Capital, Paper presented at The Third Inter-American Seminar in Economics, Rio De Janeiro, Brazil.

Lopez, R., Thomas, V., \& Wang, Y. (1998). Addressing the Education Puzzle. The Distribution of Education and Economic Reform. World Bank Policy Research Working Paper no.2031.

Maas, J. L. \& Criel, C. (1982). Distribution of primary school Enrolments in Eastern Africa, World Bank Staff Working Papers No. 511, The World Bank, Washington D.C.

Makdisi, S., Fattah, Z., \& Limam, I. (2006). Determinants of growth in the MENA region. In J. Nugent and M. H. Pesaran (Eds.), Explaining Growth in Middle East and North Africa. London: Elsevier.

Mesa, E. P. (2007). Measuring Education Inequality in the Philippines. School of Economics, University of the Philippines.

Morrisson, C., \& Murtin, F. (2007). Education Inequalities and the Kuznets Curves: A Global Perspective Since 1870. PSE Working Papers 2007-12.

Morrisson, C., \& Murtin, F. (2009). The Century of Education. Journal of Human Capital, 3(1), 1-42. http://dx.doi.org/10.1086/600102

Morrisson, C., \& Murtin, F. (2010). The Kuznets Curve of Education: A Global Perspective on Education Inequalities. Centre for the Economics of Education, CEE DP 116.

Pritchett, L. (2001). Where Has All the Education Gone? World Bank Economic Review, 15(3), 367-391. 
Qian, X., \& Smyth, X. (2008). Measuring Regional Inequality of Education in China: Widening Coast-Inland Gap or Widening Rural-Urban Gap?' Journal of International Development, 20(1), 132-144. http://dx.doi.org/10.1002/jid.1396

Ram, R. (1990). Educational Expansion and Schooling Inequality: International Evidence and Some Implications, The Review of Economics and Statistics, 72(2), 266-27. http://dx.doi.org/10.2307/2109716

Rehme, G. (2007). Education, Economic Growth and Measured Income Inequality. Economica, 74(295), 493-514. http://dx.doi.org/10.1111/j.1468-0335.2006.00555.x

Rosthal, R. A. (1978). Measures of Disparity: A Note Research Report published by Killalea Associates, Inc. Available at EDRS Price, ED149482, ERIC database.

Sahn, D. E., \& Younger, S. D. (2007). Decomposing World Education Inequality. Cornell Food and Nutrition Policy Program Working Paper No. 187.

Salehi-Isfahani, D. (2010). Human Development in the Middle East and North Africa, Human Development Research Papers HDRP-2010-26, Human Development Report Office (HDRO), United Nations Development Programme (UNDP).

Schultz, T. P. (1993). Investments in the Schooling and Health of Women and Men: Quantities and returns, Papers 702, Yale - Economic Growth Center.

Sen, A. K. (1979). Equality of What? Stanford University.

Sen, A. K. (1987). On ethics and economics. Oxford: Blackwell.

Sheret, M. (1988). Equality Trends and Comparisons for the Education System of Papua New Guinea. Studies in Educational Evaluation, 14(1), 91-112. http://dx.doi.org/10.1016/0191-491X(88)90022-3

Thomas, V., Wang, Y., \& Fan, X. (2000). Measuring Education Inequality: Gini Coefficients of Education, World Bank Policy Research Working Paper, no. WPS2525.

Thomas, V., Wang, Y., \& Fan, X. (2002). A New Dataset on Inequality in Education: Gini and Theil Indices of Schooling for 140 Countries, 1960-2000. The World Bank, Washington.

Thomas, V., Wang, Y., \& Fan, X. (2003). Measuring Education Inequality: Gini Coefficients of Education for 140 Countries (1960-2000). Journal of Education Planning and Administration, 17(1), 5-33.

Zhang, J., \& Li, T. (2002). International Inequality and Convergence in Educational Attainment, 1960-1990. Review of Development Economics, 6(3), 383-392. http://dx.doi.org/10.1111/1467-9361.00162 